\title{
2050 Left ventricular structural changes in subjects with severe uncomplicated obesity are reversible with significant weight loss. A one year follow up study Oliver J Rider*, Jane M Francis, Mohammed K Ali, Monique Robinson and Stefan Neubauer
}

Address: University of Oxford, Oxford, UK

* Corresponding author

from I th Annual SCMR Scientific Sessions Los Angeles, CA, USA. I-3 February 2008

Published: 22 October 2008

Journal of Cardiovascular Magnetic Resonance 2008, I0(SuppI I):A3I9 doi:I0.II86/I532-429X-I0-SI-A3I9

This abstract is available from: http://jcmr-online.com/content/I0/SI/A3I9

(c) 2008 Rider et al; licensee BioMed Central Ltd.

\section{Objective}

The obesity epidemic is escalating worldwide and if present trends continue, is set to become the primary cause of morbidity and mortality in the next decade. Obesity has been linked to a spectrum of cardiovascular abnormalities from subclinical changes in cardiac structure to overt heart failure, and has been liked to increased cardiovascular mortality. Uncomplicated obesity (i.e. obesity without any other co-morbidity or cardiovascular risk factors) has been shown to cause increased left ventricular mass and left ventricle dilatation. Our hypothesis was that these changes are, at least in part, reversible following significant weight loss over one year.

\section{Methods}

Forty-four obese (eight male, thirty-six female, average BMI 38.6 \pm 7.2 SD) and 15 age, sex matched controls (BMI $21.9 \pm 1.8 \mathrm{SD}$ ) underwent cardiac MR imaging at 1.5 Tesla for the assessment of left ventricular mass $(\mathrm{g})$, left ventricular end-diastolic volume (EDV; $\mathrm{ml})$, stroke volume (SV; $\mathrm{ml}$ ) and LV EF (\%). All subjects were recruited on the basis of no identifiable cardiac risk factors. There were no significant differences in fasting glucose $(5.2 \pm 0.6$ vs 4.9 $\pm 0.4 \mathrm{mmol} / \mathrm{L}, \mathrm{p}=0.10)$, cholesterol $(5.0 \pm 0.8$ vs $5.3 \pm 0.9$ $\mathrm{mmol} / \mathrm{L}, \mathrm{p}=0.27)$, systolic blood pressure $(121 \pm 13 \mathrm{vs}$ $115 \pm 10 \mathrm{mmHg}, \mathrm{p}=0.10$ ) or diastolic blood pressure (76 \pm 8 vs $73 \pm 8 \mathrm{mmHg}, \mathrm{p}=0.09$ ) between obese and normal weight subjects, with all measurements remaining in the normal range. Nineteen obese subjects underwent repeat imaging after a one year period of weight loss (fourteen with dietary intervention, five with roux-en-y gastric bypass), averaging $17 \pm 12 \%$ total body weight (range $3.5 \%$ to $47 \%$ ). Only subjects with over $3 \%$ total body weight reduction $(n=19)$ were included in the analysis.

\section{Results}

See Figure 1. Obesity per se was associated with elevated left ventricular mass $(126 \pm 28$ vs $92 \pm 24 \mathrm{~g}$; $\mathrm{p}<0.001)$, left ventricular mass indexed to height $(75 \pm 14$ vs $54 \pm 12$ $\mathrm{g} / \mathrm{m} ; \mathrm{p}<0.001)$ and end-diastolic volume $(146 \pm 20 \mathrm{vs}$ $122 \pm 22 \mathrm{ml} ; \mathrm{p}<0.001)$. End-systolic volume and stroke volume were also elevated in obesity $(46 \pm 12$ vs $39 \pm 11$ $\mathrm{ml} ; \mathrm{p}=0.035$, and $100 \pm 14$ vs $83 \pm 17 \mathrm{ml} ; \mathrm{p}<0.001$, respectively). Left ventricular ejection fraction was similar between groups ( $68 \%$ vs $68 \% ; p=0.93)$. After weight loss, there was a significant reduction in left ventricular mass (by $14 \pm 10 \mathrm{~g} ; 134 \pm 28$ vs $120 \pm 28 \mathrm{~g} ; \mathrm{p}<0.001$ ), left ventricular mass indexed to height $(79 \pm 14 \mathrm{vs} 71 \pm 13 \mathrm{~g} / \mathrm{m}$; p $<0.001)$. End-diastolic volume and end-systolic volume were significantly smaller after weight loss $(150 \pm 24$ vs $136 \pm 22 \mathrm{ml} ; \mathrm{p}<0.001$, and $45 \pm 12$ vs $40 \pm 9 \mathrm{ml} ; \mathrm{p}=0.005$ respectively). Left ventricular stroke volume was significantly reduced after weight loss $(105 \pm 16$ vs $96 \pm 14 \mathrm{ml}$; $p=0.001)$. Left ventricular ejection fraction was not altered by weight loss $(\mathrm{p}=0.663)$. 

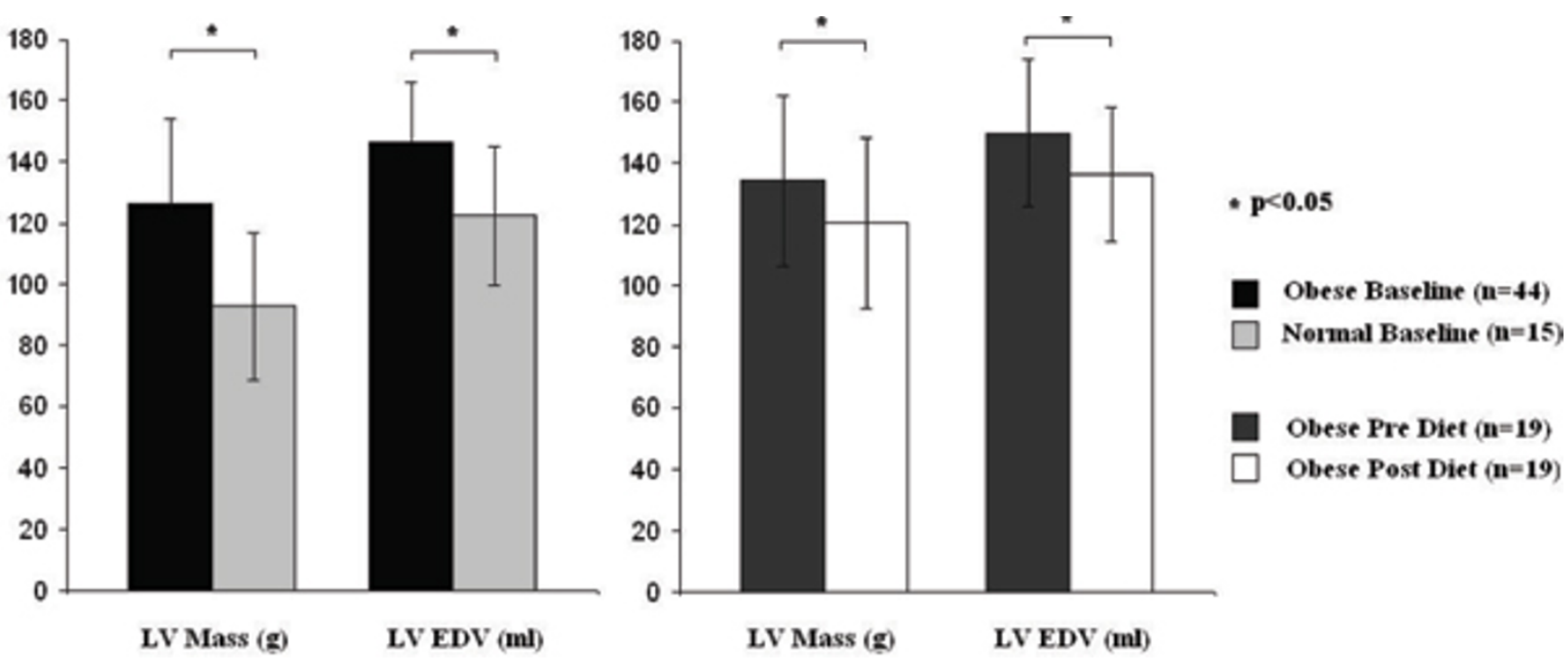

Figure I

In the setting of uncompliacted obesity, left ventricular hypertrophy and left ventricular dilatation were partially reversible after a one year period of significant weight loss.

\section{Discussion}

Left ventricular hypertrophy is linked to increased morbidity and all cause mortality, understanding the various mechanisms responsible for reversal of left ventricular hypertrophy is of great clinical importance. Cardiovascular mortality has been shown to be higher in obese individuals than normal weight individuals, and left ventricular hypertrophy may be one potential mechanism for this. Here we have shown in subjects with obesity in the absence of identifiable cardiac risk factors, left ventricular hypertrophy and left ventricular dilatation were partially reversible after a one year period of significant weight loss.

Publish with Bio Med Central and every scientist can read your work free of charge

"BioMed Central will be the most significant development for disseminating the results of biomedical research in our lifetime. "

Sir Paul Nurse, Cancer Research UK

Your research papers will be:

- available free of charge to the entire biomedical community

- peer reviewed and published immediately upon acceptance

- cited in PubMed and archived on PubMed Central

- yours - you keep the copyright

Submit your manuscript here:

http://www.biomedcentral.com/info/publishing_adv.asp
BiolMedcentral 